\title{
A GLOBALIZAÇÃO POPULAR E O SISTEMA MUNDIAL NÃO HEGEMÔNICO*
}

\section{Gustavo Lins Ribeiro}

\section{Introdução}

Existem milhões de pessoas em todo o mundo direta ou indiretamente envolvidas com o que denomino "globalização econômica de baixo para cima" ou "globalização popular", como produtores, vendedores ou consumidores. ${ }^{1}$ Quem de nós nunca viu produtos "pirateados", eletrônicos, roupas, bolsas, tênis e brinquedos ou bugigangas globais sendo vendidos em mercados populares ou por vendedores ambulantes, camelôs, em locais como o Saara, no Rio de Janeiro, a Rua 25 de Março, em São Paulo, o Shopping Oiapoque, em Belo Horizonte, a

* Uma primeira versão desse artigo foi lida na III Conferencia Esther Hermitte, Instituto de Desarrollo Económico y Social, Buenos Aires, 24 nov. 2006. Agradeço aos meus colegas do Ides, em particular a Rosana Guber, pelo honroso convite.

Artigo recebido em março/2010

Aprovado em julho/2010
Feira do Paraguai, em Brasília, em barracas e até mesmo nas calçadas de qualquer cidade?

Parte da definição de globalização popular refere-se à participação de agentes sociais que, em geral, não são considerados nas análises sobre globalização ou, quando são, figuram apenas como migrantes, ou "transmigrantes". Na maioria das vezes, não se leva em consideração a existência de um sistema mais amplo, de escala global, cujas amplitudes e interconexões várias podem ser estudadas. Os agentes sociais que me interessam são, para dizer de maneira simples e direta, gente do povo. Existe uma globalização econômica não hegemônica formada por mercados populares e fluxos de comércio que são, em grande medida, animados por gente do povo e não por representantes das elites. Uso o adjetivo popular de forma análoga a Néstor Garcia Canclini, em seu clássico As culturas populares no capitalismo (1982). Parafraseando a García Cancli$\mathrm{ni}$, posso dizer que as globalizaçôes populares, mais 


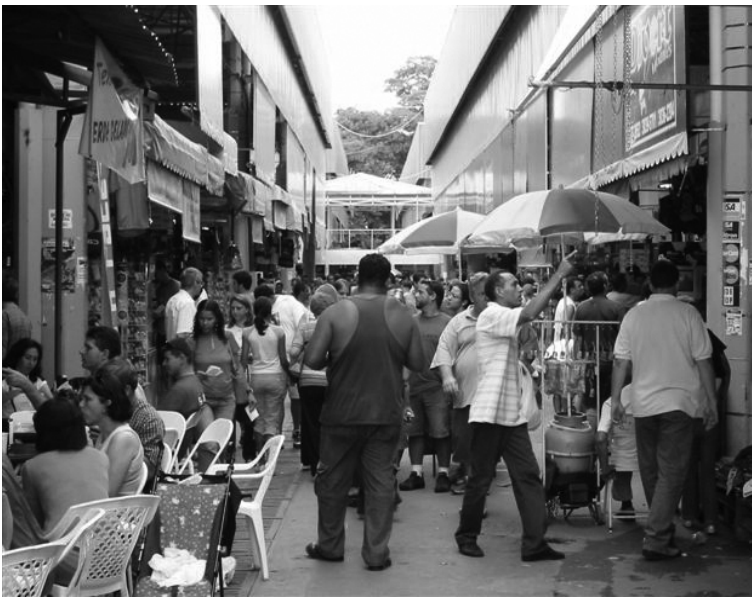

Feira do Paraguai (Brasília). Foto: Gustavo Lins Ribeiro

do que a globalização popular, "se configuram por meio de um processo de apropriação desigual dos bens econômicos e culturais" do mundo globalizado por parte de "setores subalternos" (1982, p. 62). Tais processos "são realizados pelo povo, que compartilha as condições gerais de produção, circulação e consumo do sistema em que vive [...] ao mesmo tempo em que provê suas próprias estruturas" (Idem, ibidem). Há tanto uma interpenetração como uma interação conflitiva entre o popular e o hegemônico (Idem, p. 63).

Os mercados, os fluxos e as redes de comércio da globalização popular fazem parte do sistema mundial não hegemônico. Em geral, suas atividades são consideradas ilegais, "contrabando". Uma grande quantidade das mercadorias aí vendidas é chamada de produtos piratas pelos poderes estabelecidos. Essas atividades são ilegítimas do ponto de vista dos poderosos, que as combatem em nome da legalidade. Assim, é impossível entrar nessa arena sem primeiro tocar na discussão sobre o que é legal/ ilegal, lícito/ilícito.

\section{Legal/ilegal - Lícito/ilícito}

Hoje, a "ilicitude global" chama a atenção por sua escala e poder. Moisés Naím, editor da revista Foreign Policy, publicou, em 2005, Ilícito, um livro canônico da literatura conservadora dedicada a propalar, no dizer de Abraham e Van Schendel, a exis- tência de "um espectro que assombra a globalização", o espectro do crime organizado internacional (2005, p. 2). Com o sugestivo subtítulo "O ataque da pirataria, da lavagem de dinheiro e do tráfico à economia global", o livro de Naím apresenta uma visão alarmista de como o "comércio global ilícito", que movimenta centenas de bilhões de dólares por ano, representa uma ameaça à boa saúde da sociedade e do capitalismo contemporâneos. É curioso que seu autor acabe por defender a tese, nada neoliberal, de que a crescente debilitação dos Estados, provocada pela intensificação da globalização, é fator primordial para o aumento das atividades ilícitas no mundo. Naím dá uma definição de "comércio global ilícito" emblemática da interpretação conservadora:

É o comércio que rompe as regras - leis, regulações, licenças, impostos, embargos e todos os procedimentos que as naçôes empregam para organizar os negócios, proteger seus cidadãos, levantar recursos e implementar códigos morais. Inclui compras e vendas que são estritamente ilegais em todas as partes e outras que podem ser ilegais em alguns países e aceitas em outros. O comércio ilícito é altamente prejudicial, claro, para os negócios legítimos. Mas há exceções. Pois [...] há uma enorme área cinza entre transaçôes legais e ilegais, uma área cinza que os comerciantes ilícitos têm usado em benefício próprio (2005, p. 2).

Para Naím, o "comércio global ilícito" floresce e triunfa em um mundo mais interconectado, com fronteiras mais porosas e poderosas tecnologias (como a internet) em mãos de "civis", com menos barreiras ao comércio e mais agentes não estatais operando no cenário internacional. O presente é o paraíso do contrabandista. O crime organizado, apesar de crescentemente descentralizado e operando em rede, tem aumentado seu poder político, chegando a tomar importantes parcelas dos Estados mais fracos. $\mathrm{O}$ autor considera que, apesar da antiguidade das atividades ilícitas no plano internacional, a intensidade atual coloca o fenômeno em um novo patamar. Mesmo com o seu viés conservador (o livro é vazado em uma linguagem em que o bem 
está sendo sufocado pelo mal), Naím deixa claro que o sistema mundial não hegemônico só tende a crescer com o aumento da compressão do tempoespaço, das redes postas em ação pelo capitalismo flexível e do enfraquecimento da capacidade de intervenção e regulação dos Estados. O caráter sistêmico do "comércio global ilícito" é explicitado no livro quando o autor analisa a existência de um sistema formado por redes e nós. Em sintonia com sua visão negativa, Naím vê uma oposição global entre dois polos que leva à colisão entre "pontos claros geopolíticos” e "buracos negros geopolíticos". Os últimos são "os lugares onde as redes de tráfico 'vivem' e desabrocham” (Idem, p. 261), podendo coincidir com (1) Estados-nação, onde não existe o Estado de direito; (2) regióes fora da lei e anárquicas, internas a alguns países, como as áreas montanhosas da Córsega e os estados mexicanos da fronteira com os Estados Unidos; (3) áreas de fronteira, como o Triângulo de Ouro do Sudeste Asiático ou a Tríplice Fronteira na América do Sul; (4) sistemas de vizinhanças e localidades, como as comunidades libanesas nas capitais da África Ocidental; e (5) espaços na internet. A diferença entre pontos claros e buracos negros geopolíticos não está na presença ou na ausência de redes ilícitas, pois estas "estão em todas as partes" (Idem, p. 263), mas na existência de capacidade cívica e estatal suficiente para se contrapor a elas. Para Naím,

[...] um fator crucial - que dá aos buracos negros boa parte de sua potência - é sua capacidade de conexão especializada com os pontos claros. Uma região remota, primitiva e mal governada - ou desgovernada - não é um buraco negro geopolítico a não ser que possa irradiar ameaças a lugares distantes. As redes de comércio que operam internacionalmente servem como canais por meio dos quais tais ameaças se movimentam de lugares remotos para o resto do mundo (Idem, pp. 264-265).

Em sua interpretação, pontos claros e buracos negros mantêm relaçôes e fazem parte de redes que atravessam os Estados-nação. Quanto mais claro um ponto, mais atrativo será para as redes dos buracos negros oferecerem seus serviços e produtos, especialmente porque a diferença de preços é o fator determinante no comércio ilícito. Naím explora sua metáfora do claro/escuro:

[...] quanto mais claro o ponto claro, mais altos os preços que esses bens ilícitos podem obter. Quanto mais escuro o buraco negro, mais desesperadas as pessoas estarão para vender seus bens, suas mentes, seu trabalho e até mesmo seus corpos aos traficantes. Juntas, essas duas tendências criam diferenciais de preços cada vez maiores e, portanto, incentivos cada vez maiores para conectar buracos negros a pontos claros (Idem, p. 265).

A análise de Naím, por mais sofisticada e consubstanciada que possa parecer, incorre em problemas típicos de interpretações destinadas a replicar a hegemonia existente. Em primeiro lugar, está marcada por um americanocentrismo imperial, como se essa fosse a ordem natural das coisas. Não consegue perceber, ou não se preocupa com isso, que a dicotomia "ponto claro/buraco negro" tem sido historicamente construída em termos de relações desiguais de poder entre diferentes setores sociais, econômicos, políticos e étnicos do sistema mundial que criam uma economia política global peculiar. Além disso, as relações entre os pontos claros e os buracos negros são por ele consideradas de maneira simplificada, ao subestimar o trânsito entre os dois. Por último, em um viés típico da análise dos poderosos, o autor homogeneíza os atores, em especial os integrantes do que denomino sistema mundial não hegemônico. São todos, dos "sacoleiros" aos membros de cartéis de droga, colocados no mesmo saco, imersos que estão em um universo cuja caracterização como ilegal é tomada como natural e moralmente óbvia.

$\mathrm{Na}$ verdade, a questão dos limites entre o legal e o ilegal, questão à primeira vista pacífica, quando examinada mais de perto se revela mais complicada do que uma disputa entre honestos e desonestos, entre o bem e o mal, e acerca-se muito mais do problema histórico da distribuição desigual de poder em um mundo econômica, política e culturalmente diferenciado. Muitos dos agentes e corporaçôes capitalistas que hoje supostamente são cumpridores da lei e se encontram pretensamente vulneráveis à voracidade de novos agentes econômicos ilegais, 
estão ou estiveram em uma posição onde a linha legal/ilegal tampouco é ou era respeitada (Nordstrom, 2007). Qualquer visão que absolutize a rigidez e a eficiência desta linha, absolutiza, para fins ideológicos, a eficácia quase panótica, a honestidade, a independência e a neutralidade totais da atuação do Estado, fato que não resiste a um escrutínio sociológico e histórico maior. Como afirma Telles, "o fato é que as relações incertas entre o lícito, o ilegal e o ilícito constituem um fenômeno transversal na experiência contemporânea” (2009, p. 156).

Mas, nesta discussão, assim como em outras correlatas como, por exemplo, a da economia informal, a entidade central em jogo é o Estado. São as elites estatais que têm, ao longo dos séculos, mantido o monopólio da definiçãao e da regulação da legalidade/ilegalidade. É efetivamente o que apontam trabalhos como o de Josiah Heyman e Alan Smart. Para eles:

A lei dos Estados inevitavelmente cria suas contrapartidas, zonas de ambiguidade e ilegalidade aberta. Submundos criminosos, piratas e quadrilhas, mercados negros, migrantes ilegais, contrabandistas e redes de extorsão são tópicos que causam uma certa atração sensacionalista ou talvez desafiadora. Mas não existem separados do Estado, nem o Estado deles. Tendo se desenvolvido necessariamente conectadas, a lei estatal e a sua evasão devem ser estudadas juntas [...] é interessante pesquisar as condiçōes sob as quais governos e práticas ilegais gozam de algum tipo de simbiose e aquelas que resultam em maiores ou menores graus de conflito (1999, p. 1).

A tentativa de caracterizar atividades ilegais em termos morais ou restritos aos lucros extras que elas gerariam é criticada, em especial, por Alan Smart. Para ele existem diversos mecanismos centrais na produção e na distribuição de bens e serviços ilegais, que incluem "a confiança interna a redes, ameaças de uso de força, unir transações ilícitas a outras legais, a legitimidade da transação, a importância da reputação para os empreendedores ilegais e sua dependência de funcionários e instituiçôes corruptos" (Idem, p. 5). Além disso, há que incluir as formas sobre as quais a sociedade está estruturada, a dinâmica do seu poder político e de suas políticas econômicas, tanto quanto conjunturas econômicas e percepções culturais sobre corrupção (Tullis, 1995, apud Heyman e Smart, 1999, p. 5). Para entender o que efetivamente ocorre, é preciso ir além de uma perspectiva negativa, baseada em um pretenso monopólio moral da honestidade por parte de um segmento social. É preciso, no dizer de Heyman e Smart, ir além do formalismo legal e político para reconhecer que "ilegalidade não necessariamente significa que as atividades são ilegítimas quando há hegemonias incompletas e práticas estatais parciais e frequentemente comprometidas" (Idem, p. 8). A análise histórica também tem demonstrado, em especial quando se trata dos primórdios do Estado moderno e interventor, a forte relação entre o Estado e redes violentas, tanto quanto o papel da predação na acumulação de capital (Idem, ibidem). Ao mesmo tempo, apesar da crescente capacidade de impor a lei que acompanhou a consolidação dos Estados a partir do século XIX, "não há nenhuma razão para se supor que a capacidade do Estado de impor obediência aumente sempre, ou que desafiar a lei seja um resultado temporário da ineficiência e de táticas inapropriadas da aplicação da lei" (Idem, p. 9). Para eles, o Estado moderno "não é feito apenas de lei e ordem, mas é uma teia complexa do legal e ilegal" (Idem, ibidem).

Das reflexões de Heyman e Smart destaco as que apontam para a imperfeição, a incompletude e o caráter processual do Estado e de sua dominação; a inevitável geração de mercados de bens e serviços ilegais em resposta às regulações oficiais estatais; a persistência de práticas ilegais e informais (como a oferta de propinas e presentes); a atuação diferenciada dos agentes estatais concretos; a manipulação da legalidade, por parte de diferentes atores interna e externamente ao Estado; a consideração das práticas ilegais não como um estigma, mas como um recurso utilizado por diferentes grupos em vários momentos, tendo em vista que a ilegalidade é uma instância ou posição de um campo social típico do Estado moderno. São igualmente importantes suas conclusões sobre o caráter relacional das práticas ilegais que sempre existem em um campo de relações sociais atravessado por classes sociais, pela presença 
do Estado e o acesso diferenciado a recursos sociais e naturais. Ao mesmo tempo em que apontam para o entrelaçamento entre o legal e o ilegal e para a diversidade das práticas ilegais, afirmam que estas últimas não devem ser vistas como monopólio de criminosos: "mercados ilegais, corrupção e fluxos não documentados de capitais são opçōes feitas por classes identificáveis, grupos regionais, grupos étnicos etc., em diferentes momentos" (Idem, p. 13).

Com efeito, as relaçōes entre o legal e o ilegal são multifacetadas e complexas, envolvendo interesses normativos, políticos e morais diversos. No que diz respeito ao sistema mundial não hegemônico, sua compreensão pode ser enriquecida também por abordagens cujo foco se move nas fronteiras entre a economia informal e a economia ilícita (Sousa, 2004) e entre o ilícito e o ilegal (Abraham e Van Schendel, 2005). No processo de apresentar as distinçōes e as definiçōes cruciais na construção da noção de sistema mundial não hegemônico, é preciso estabelecer uma distinção fina (a) entre economia informal e ilícita e (b) entre o que é ilegal e ilícito.

Não é meu propósito entrar na vasta discussão sobre economia informal ou mercado informal. Nela encontra-se um debate com grande incidência sobre o que me ocupa aqui: o poder de regulação do Estado; a consideração da legitimidade da prática dos atores econômicos; a relação entre universos formais e informais; o papel da confiança, das redes sociais etc. Tampouco chamarei a globalização popular de economia informal global, pois creio que a ênfase sobre hegemonia é mais esclarecedora das relaçôes em jogo. Para efeito dos meus objetivos neste artigo, é suficiente considerar a diferenciação entre economia informal e economia ilícita que faz Rosinaldo Silva de Sousa, pois permitirá deixar clara a distinção central que faço entre crime organizado global e a globalização popular. Friso que o que Souza chama de "economia informal" equivale para mim, no plano global, à globalização popular. Para Sousa o "sistema de comércio ilícito", do qual faz parte o narcotráfico, por exemplo, e a "economia informal" compartilham duas características gerais para seu funcionamento: o uso da corrupção mais a importância do "valor confiança" e de certos princípios de reciprocidade (Lomnitz, 1988, 1994).
Entretanto, para o sistema de comércio ilícito há um terceiro fator crucial, marginal à dinâmica da economia informal: o uso da violência. Em suma, Souza distingue a economia informal da ilícita de acordo com as relaçôes sociais diferenciadas características de cada uma. $\mathrm{Na}$ informal, que se beneficia da omissão do Estado, prevalecem o "valor confiança" e certos princípios de reciprocidade; seus agentes não ambicionam o domínio dos meios da violência. Já na economia ilícita, confiança e reciprocidade também estão presentes, mas prevalecem a violência ilegítima e a corrupção de agentes públicos. Aqui, trata-se de uma violência instrumental racionalizada, "um meio que opera sob um relativo controle nos negócios ilícitos e que coíbe certas condutas contraproducentes para o incremento da riqueza ilícita" (Sousa, 2004, p. 170). Para mim, então, uma diferença fundamental entre o crime organizado global e a globalização popular refere-se à falta de centralidade, nesta última, da violência como fator regulador das atividades econômicas, em especial, no que diz respeito à validade dos contratos entre os agentes econômicos.

Já Abraham e Van Schendel enfatizam a diferença entre legal, "o que Estados consideram como legítimo", e lícito, "o que as pessoas envolvidas em redes transnacionais consideram como legítimo" (2005, p. 4). Assim, muitos fluxos de pessoas, mercadorias e informações são considerados ilícitos porque desafiam as normas das autoridades formais, mas são considerados lícitos pelas pessoas envolvidas nas transaçôes. Argumentam que há "uma diferença qualitativa de escala e intenção entre as atividades de quadrilhas internacionalmente organizadas e as múltiplas micropráticas que, apesar de ilegais em um sentido formal, não são motivadas por uma lógica estrutural organizativa nem por um propósito unificado" (Idem, ibidem).

Para analisar as linhas fluidas entre o lícito e o ilícito no mundo de fluxos globais, Abraham e Van Schendel lançam mão das noçôes de "cadeias de mercadorias" (trajetos percorridos pelos bens, da sua produção ao consumo) e de "espaços regulatórios" (zonas nas quais conjuntos específicos de normas ou regras, estatais ou sociais, são dominantes). Trata-se de uma opção interpretativa bastante produtiva para pensar práticas transnacionais. Eles 
definem as "atividades criminosas transnacionais" como "formas de práticas sociais que intersectam dois ou mais espaços regulatórios e violam ao menos uma regra normativa ou legal" (Idem, p. 15). Como se sabe, a produção, a circulação e o consumo de mercadorias podem ocorrer em espaços circunscritos ou atravessar diferentes espaços regulatórios. Dessa forma, determinadas mercadorias que entram em determinados fluxos e atravessam certos espaços regulatórios podem se transformar de legais em ilegais ou vice-versa. Por exemplo, caixas de uísque escocês podem ser produzidas e exportadas legalmente para um país, introduzidas e vendidas ilegalmente em outro. A produção de folhas de coca na Bolívia é outro exemplo interessante de como os sinais se transformam de acordo com espaços regulatórios diferentes. Se produzida em determinadas áreas do país e em quantidade específica, a folha de coca é legal e sua produção tida como legitimamente direcionada ao consumo tradicional das populaçōes indígenas. Fora disso, sua produção é ilegal e passa a ser suspeita de estar direcionada à cadeia de mercadorias que leva ao consumidor de cocaína (ver Sousa, 2006). A lavagem de dinheiro é vista por Abraham e Van Schendel como um exemplo de legalização nas transformações possíveis do par lícito-ilícito. A conversão de drogas ilegais em dinheiro permite, por meio da lavagem, a movimentação em fluxos lícitos. Para eles, "o que determina a legalidade e a ilegalidade em diferentes pontos da cadeia de mercadorias é a escala regulatória específica em que o objeto se encontra” (2005, p. 17). Por isso é importante identificar a "origem da autoridade regulatória” e, em consequência, "distinguir entre as origens política (legal e ilegal) e social (lícita e ilícita) da autoridade regulatória" (Idem, ibidem). Lícito/ilícito, então, dizem respeito muito mais às percepçôes sociais do que à letra da lei.

Ao introduzir o conceito de legitimidade social ou licitude e contrastá-lo com legitimidade política ou legalidade, procuramos ressaltar a natureza politicamente derivada desta distinção e suas bases morais-institucionais, no intuito de ajudar a desnaturalizar a Lei como a condição do sentido comum do espaço doméstico nacional (Idem, p. 31).
Diante das dificuldades de encontrar soluçōes universais para as contradições existentes entre o par legal/ilegal e o par lícito/ilícito, especialmente no âmbito transnacional que atravessa as leis emolduradas pelos Estados-nação, Abraham e Van Schendel constroem uma noção que, em última instância, tem sua definição determinada pelos cruzamentos entre o lícito e o ilegal e entre o ilícito e o legal: o (i)lícito. Interessam-se especialmente pelo cruzamento entre o lícito e o ilegal que cria um espaço onde o (i)lícito significa atividades "legalmente banidas mas socialmente sancionadas e protegidas" (Idem, p. 22), como, acrescento, aquelas que animam a globalização popular, isto é as atividades dos "sacoleiros" e dos mercados populares de superlogomarcas e gadgets globais. Em muitos contextos, o "socialmente lícito" domina o "formalmente ilegal" como, exemplificam os autores, na venda, no Paquistão, de filmes indianos em DVDs. A visibilidade e o caráter rotineiro das atividades ilegais não significam que o Estado deixe de reprimi-las, algo que frequentemente é feito pela polícia em momentos de elevado sentido de "missão cívica e pública" (Idem, ibidem).

\section{Uma advertência antes de prosseguir}

Ao entrar em um universo de práticas e representações sociais altamente permeado por valores em que o bem e o mal são muitas vezes absolutizados, a análise sociológica e antropológica corre o risco de ser, em uma leitura conservadora, acusada de glamorizar o crime e satanizar o Estado. É claro que, nestes contextos complexos e delicados, não se trata nem de uma coisa nem da outra. Reconhecer que as linhas entre o legal e o ilegal são definidas por relaçóes históricas de poder e pelo exercício de hegemonia não implica uma posição relativista, onde tudo que é ilegal seja aceitável ou que toda legalidade seja absurda. Neste universo, os dilemas da pesquisa antropológica crítica encontram-se no meio de várias tensões cujo fiel da balança é o bom senso do pesquisador. Ao mesmo tempo em que não é possível absolutizar o Estado e a legalidade, tampouco se pode romantizar as práticas ilegais. A questão é bem resumida por Heyman e Smart: 
Muito do que é ilegal é perigoso, e muito do que é legal é razoável. Tanto a fraude financeira como a violência física devem ser proibidas, processadas e punidas. $\mathrm{O}$ mero fato de que a ilegalidade persista e frequentemente se entremeie com o mundo legal e formal não justifica uma posição puramente relativista. Da mesma forma, apesar de o Estado ser um instrumento de força organizada e de predação (impostos), na medida em que incorpora elementos razoáveis da lei, não se equipara inteiramente à força e à predação ilegais. Contudo, não podemos sustentar o inverso, isto é, que tudo que o Estado formal faz é moralmente eficaz e que todas as atividades ilegais são imorais e deveriam ser suprimidas. Isto não se sustenta nem no sentido empírico [...] nem no sentido moral. Neste último caso, muitas atividades rotuladas como ilegais têm uma ampla vida legítima na sociedade (ou em grupos particulares) e, nestas circunstâncias, a resposta estatal constitui má legislação, incrementando a ilegalidade, incluindo aqui "guerras" de todos os tipos, que são moralmente piores do que a violação original. $\mathrm{O}$ trabalho acadêmico cuidadoso, que transcenda a suposição de que toda lei formal é boa e que toda ilegalidade é um "problema" a ser eliminado e, ao mesmo tempo, aponte o balanço específico em cada caso, pode informar as escolhas morais públicas que temos que fazer (1999, p. 21).

\section{O sistema mundial não hegemônico}

Primeiramente, farei uma rápida consideração histórica, quase uma digressão, para evitar um problema comum quando o assunto é globalização: a tendência a crer de que se trata de fenômenos novos que jamais aconteceram. Muitas das mercadorias que são vendidas no âmbito da globalização popular são verdadeiros simulacros, para usar a expressão de Jean Baudrillard, cópias com altos graus de perfeição. Na verdade, a produção de cópias não autorizadas é uma atividade milenar. Alem disso, não por acaso, a pirataria é, hoje, uma expressão comumente usada pelos poderosos para se referir à atividade de reprodução e venda de cópias não-autorizadas de mercadorias valorizadas pelos consumidores contemporâneos, especialmente as superlogomarcas, isto é, cópias de grandes marcas mundiais (Chang, 2004). A pirataria é uma atividade muito antiga e historicamente tem sido um desafio e uma alternativa aos modos predominantes de vida, trabalho e comércio:

Apesar do grande risco da pessoa ser capturada e executada pelos seus feitos, a pirataria foi uma alternativa atraente a morrer de fome, tornarse um mendigo ou ladrão, ou servir, em condiçôes extenuantes, em um barco sem nenhuma chance de recompensa financeira substancial (Konstam, 2002, p. 9).

A pirataria sempre foi um problema para os poderes estabelecidos. Há registros da atividade de piratas no Mar Mediterrâneo anteriormente à época do Egito antigo (Idem, ibidem). Foi apenas quando Roma conseguiu impor seu poder naval que as comunidades piratas do Mediterrâneo desapareceram. Mas claro que a pirataria não. Ela floresceu, por exemplo, no século XVII e XVIII, a chamada "era dourada da pirataria" (1690-1730), no Mar do Caribe, na costa atlântica da América, na costa da África Ocidental e no Oceano Índico (Idem, ibidem). Há evidências de que comunidades piratas em diferentes partes do mundo exerceram poder econômico importante, inclusive transformando-se em centros regionais. Thomas Gallant, por exemplo, considera que em vários lugares "empreendedores militares, como bandidos e piratas, proveram o tecido que articulou o interior rural a zonas econômicas em desenvolvimento. Suas atividades facilitaram a penetração capitalista" (1999, p. 37). Até o presente, piratas modernos regularmente atacam barcos que atravessam o mar do sul da China e as costas da Somália.

A existência de protossistemas mundiais não hegemônicos foi impulsionada pelo trabalho dos marinheiros que conectavam as terras do Novo Mundo às da Europa, criando a circulação de ideopanoramas diferentes daqueles das classes hegemônicas. Assim, ideias alternativas de sociedade, baseadas no comunismo primitivo do Novo Mundo, 
informaram várias utopias europeias séculos atrás (Linebaugh e Rediker, 2000, p. 24). Estes dois historiadores afirmam que quando, entre $1680 \mathrm{e}$ 1760 , se consolidou e se estabilizou o capitalismo no Atlântico "o barco a vela - a máquina típica deste período de globalização - combinava características das fábricas e da prisão. Em contraste, piratas construíram uma ordem social autônoma, democrática e multirracial no mar" (Idem, p. 328).

Como se vê, os proletários da expansão capitalista marítima (os marinheiros) e os agentes sociais que representavam uma ameaça aos interesses hegemônicos estatais e privados por trás desta expansão (os piratas) estiveram historicamente envolvidos, em maior ou menor grau, e com maior ou menor eficácia, na construção de sistemas mundiais não hegemônicos. A antiguidade dos "padrôes de movimento, comércio e trocas que caracterizam o tráfico ilícito" também é indicada por Abraham e Van Schendel (2005, p. 5), que exemplificam com transações mantidas durante séculos por redes étnicas e de parentesco entre as costas do Golfo Pérsico e Gujarat, na Índia. Tais situações mostram a complexidade das interconexôes mantidas por diferentes populações ao longo do tempo, interconexões fundamentais para a criação do sistema mundial.

$\mathrm{Na}$ antropologia, o livro clássico Europe and the people without history, de Eric Wolf (1982), é o relato mais denso sobre os processos históricos de interconexões que criaram o sistema mundial. Mas, a noção de sistema mundial está associada diretamente ao livro de Immanuel Wallerstein publicado originalmente em 1974: O moderno sistema-mundial: agricultura capitalista e as origens da economiamundo européia no século XVI. Aqui, o uso que faço da noção de sistema-mundial é seletivo. Não está tão próximo à discussão sobre centro, periferia e semiperiferia, importantes elementos da concepção wallersteiniana tomados de empréstimo da discussão sobre dependência. Do conceito de sistemamundial interessam-me muito mais os seguintes aspectos destacados por Wallerstein:

[...] não estamos falando de sistemas, economias, impérios do mundo (todo), mas de sistemas, economias, impérios que são um mundo (que muito possivelmente, na verdade com frequência, não incluem todo o globo). Este é um conceito-chave a considerar. Significa que quando falamos de "sistemas-mundiais" estamos lidando com uma zona espaço/temporal que atravessa muitas unidades políticas e culturais, representando uma zona integrada de atividade e instituições que obedecem a certas regras sistêmicas (2006, pp. 16-17).

É justamente o que o sistema-mundial não hegemônico é: uma composição de várias unidades localizadas em diferentes glocais conectados por agentes operando na globalização popular. Esta é formada por redes que operam de maneira articulada e que, em geral, se encontram em diferentes mercados que formam os nós do sistema mundial não hegemônico. Essa articulação cria interconexões que dão um caráter sistêmico a este tipo de globalização e faz com que suas redes tenham alcance de longa distância. O sistema-mundial nãohegemônico conecta muitas unidades no mundo por meio de fluxos de informação, pessoas, mercadorias e capital.

Se chamo este sistema de não hegemônico é porque existe um sistema hegemônico. ${ }^{2} \mathrm{Na}$ verdade, os dois sistemas podem ser definidos pelas relações que mantêm entre si e guardam analogias com o que Naím (2005) chamou de buracos negros e pontos claros. $\mathrm{O}$ sistema hegemônico reflete a lógica institucional e operativa dos detentores de poder tanto no que diz respeito ao Estado como ao capital privado. Nas últimas décadas, o sistemamundial hegemônico tem sido dominado pelos interesses da globalização capitalista neoliberal. No sistema hegemônico, que guarda relações íntimas com o poder estatal, os agentes econômicos conseguem gerar e manter a aparência para a sociedade como um todo de que detêm o monopólio da legitimidade e legalidade das transaçóes econômicas, mesmo quando envolvidos ou surpreendidos em atividades ilegais. Um bom exemplo é o que acontece nos portos. Nos mais organizados e operacionalmente capazes, apenas $5 \%$ da carga de contêineres é efetivamente inspecionada (Nordstrom, 2007). A imensa maioria do contrabando é, assim, realizada pelas corporações: 
A mídia e a cultura popular apontam obscuras organizações criminosas como os principais contrabandistas, mas, de fato, empresas legítimas e as corporaçōes multinacionais são os principais transgressores. Subfaturamento e fazer declaraçōes falsas sobre as mercadorias embarcadas são açôes básicas nesse negócio (Idem, pp. 119-120).

Já o sistema mundial não hegemônico nos leva a outros raciocínios e pode ser definido de maneira análoga à minha interpretação sobre a globalização econômica não-hegemônica (Ribeiro, 2006), uma categoria similar à de sistema mundial não hegemônico, mas na qual a sistematicidade da globalização popular não é o foco da questão. Denomino este sistema de não hegemônico e não de anti-hegemônico, porque seus agentes não intencionam destruir o capitalismo global ou instalar algum tipo de alternativa radical à ordem prevalecente. É não hegemônico porque suas atividades desafiam o establishment econômico em todas as partes, nos níveis locais, regionais, nacionais, internacionais e transnacionais. Consequentemente, seus agentes são retratados como uma ameaça ao establishment e sentem o poder das elites políticas e econômicas que querem controlá-los. São reveladoras as atitudes que os Estados e as corporaçôes têm com relação a práticas do sistema não hegemônico. A maior parte do tempo tais atividades são tratadas como assunto de polícia, sendo objeto de ação repressiva elaborada. O sistema mundial não hegemônico é um universo enorme que envolve, sim, atividades ilegais, tais quais tráficos de pessoas e de órgãos, que precisam ser reprimidas. De toda forma, trabalhadores, como camelôs, cujo "crime" é trabalhar fora dos parâmetros definidos pelo Estado, são uma parte expressiva da globalização não hegemônica.

O sistema mundial não hegemônico está formado por diversos tipos de segmentos e redes que se estruturam como uma pirâmide. No topo há esquemas de lavagem de dinheiro, atividades mafiosas, todo tipo de corrupção. Não importa quão poderosos e elitistas sejam muitos dos agentes envolvidos no sistema não-hegemônico, eles não podem atuar sozinhos. Há envolvimento maciço de pessoas pobres nos segmentos mais baixos dessa estrutura pira- midal. Para esses agentes sociais, o sistema mundial não hegemônico é um modo de vida e de conseguir mobilidade social ascendente. Networking e intermediações cimentam esta estrutura piramidal de forma comparável ao que chamei de consorciação, um processo típico das articulações entre agentes transnacionais, nacionais, regionais e locais ao redor de grandes projetos de infra-estrutura multibilionários (Ribeiro 1991; 2008). As atividades na base da pirâmide são o que chamo de verdadeira globalização de baixo para cima. Proveem acesso a fluxos de riquezas globais que de outra forma nunca chegariam aos segmentos mais vulneráveis de qualquer sociedade ou economia. Elas abrem um caminho para a mobilidade ascendente ou a possibilidade de sobrevivência em economias nacionais e globais que não são capazes de prover pleno emprego a todos cidadãos. Estou interessado neste segmento do sistema não hegemônico e não nos seus escalōes superiores. De qualquer maneira, é necessário reiterar uma distinção crucial para a compreensão do sistema mundial não hegemônico, aquela entre crime organizado global e globalização popular.

O sistema mundial não hegemônico é formado por dois tipos básicos de processos de globalização, cujas fronteiras não são necessariamente nítidas nem rígidas (ver discussão conceitual anterior, na segunda seção deste artigo). O primeiro é formado pela economia ilegal global, aquela que envolve as atividades do crime organizado global. O segundo é formado pela economia (i)licita global, aquela que envolve as atividades do que chamo de globalização popular e que são frequentemente consideradas ilegais pelo Estado e lícitas pela sociedade. $\mathrm{Na}$ verdade, são processos que podem se entrelaçar, retroalimentar e manter relaçōes hierárquicas. Por exemplo, ainda que a atividade de globalização popular seja, do ponto de vista do Estado, caracterizada como contrabando, é bastante diferente se consideramos o chamado "contrabando formiga" na fronteira Argentina/Paraguai (Schiavoni, 1993) ou grandes esquemas de contrabando controlados por quadrilhas organizadas. Assim, aquilo que em geral é indistinto do ponto de vista do Estado, do meu ponto de vista pode ser parte da economia (i)lícita global (da globalização popular) ou da economia ilegal global (do crime organizado). 
A importância das redes sociais no funcionamento desse universo é destacada na literatura. Heyman e Smart formularam uma definição de "rede ilegal" útil para pensar a economia ilegal global. Trata-se, para eles, de uma "teia ordenada de pessoas centradas em uma atividade ilegal”, redes que implicam, mas não necessariamente requerem, "um mundo social alternativo ao Estado formal e legal". Tais redes são vitais para as práticas ilegais dadas suas características de relações baseadas em mutualidade, confiança e trocas (1999, p. 17). Na minha perspectiva, as redes sociais ilegais realizam suas práticas ilegais internamente a uma estrutura hierárquica em que prevalecem a conspiração e o planejamento centralizado, assim como o uso da violência ilegítima. Se trocarmos o adjetivo "ilegais" por (i)lícitos, poderemos buscar, analogicamente, uma definição para pensar a economia (i)lícita global. Assim, na globalização popular, operam as redes sociais (i)lícitas de forma descentralizada, horizontal e baseadas em valores de confiança. As redes sociais (i)lícitas realizam suas práticas (i)lícitas sobre ou a partir de sistemas informais previamente construídos por diásporas, redes migratórias ou formas típicas da economia popular (feiras e seus sistemas de mercados associados, por exemplo).

Por outro lado, Naím chama a atenção para o caráter simultaneamente global e local das redes envolvidas no que chamo de sistema mundial não hegemônico e para a habilidade que têm de explorar, com rapidez, sua mobilidade internacional, o que em muito potencializa sua capacidade de escapar ao controle dos Estados nacionais (2005, p. 34). Além disso, é preciso enfatizar a flexibilidade dessas redes. Como todas as redes sociais, as ilegais/(i)lícitas podem se unir e desfazer de acordo com as circunstâncias e seus interesses. Podem se desfazer, por exemplo, quando uma atividade ilegal não é mais necessária ou proveitosa. Grandes redes ou articulações extensas de redes não são estritamente necessárias para realizar conexões de longa distância, ou até globais. De fato, as mercadorias que fluem internamente ao sistema mundial não hegemônico podem mudar de mãos várias vezes, atravessando vários espaços regulatórios, até chegarem aos consumidores finais.
Dessa forma, o sistema está formado por uma rede intricada de nós, que são pontos de interconexão entre vendedores e compradores. Tais nós variam em tamanho e importância para a reprodução do sistema, podendo ser desde pequenos aglomerados de barracas de camelôs destinados a atender as necessidades de consumidores finais, até megacentros, em grande medida destinados a intermediários, cuja influência econômica tem alcance internacional, como os localizados em Dubai, nos Emirados Árabes Unidos, abastecendo diversos países europeus (Tarrius, 2007, apud Telles, 2009), ou no "espaço social transfronteiriço" de Foz do Iguaçu - Brasil/Ciudad del Este - Paraguai (Rabossi, 2004; Machado, 2005, 2009). ${ }^{3}$ Há também megacentros de alcance nacional, como a Rua 25 de Março, em São Paulo (Schaden, 2005; Nascimento, 2006), e Tepito, na Cidade do México, que servem agentes da globalização popular operando em um raio que pode alcançar alguns milhares de quilômetros e cruzar países. Tepito, por exemplo, el tianguis global (tianguis significa camelódromo em nahuatl, língua indígena ainda largamente falada no México) liga, via redes migratórias, a Cidade do México a Los Angeles, nos Estados Unidos (Alarcón, 2008). Há ainda importantes centros de atuação regional ou local como, na Colômbia, os San Andresitos (em alusão à ilha caribenha e porto livre de San Andrés); no Brasil, as Feiras do Paraguai em Caruaru (Lyra,

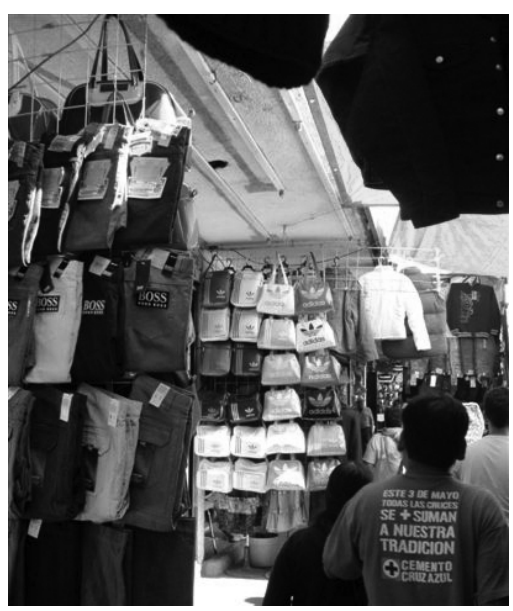

Superlogomarcas em Tepito (Cidade do México) Foto: Gustavo Lins Ribeiro 


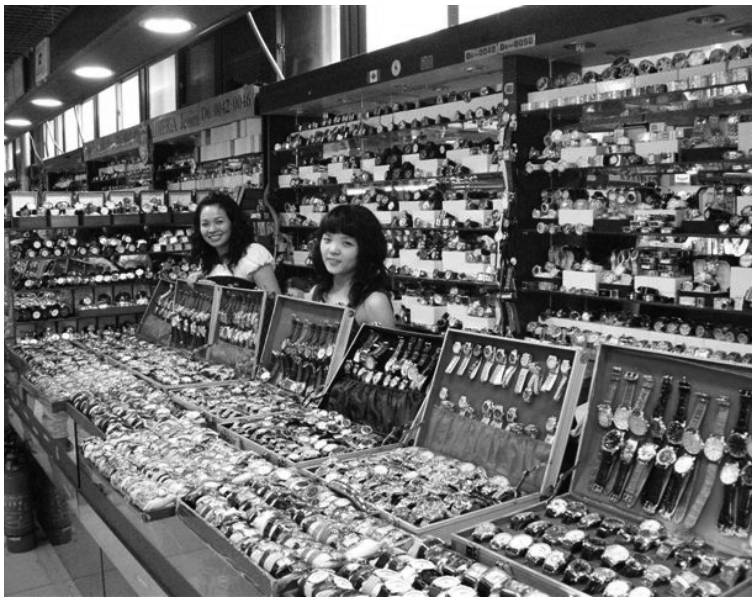

Relógios no Mercado da Seda (Xiu Shui) em Pequim. Foto: Gustavo Lins Ribeiro.

2005) e em Brasília (Souza, 2000; Figueiredo, 2001), a área do centro do Rio de Janeiro conhecida como Saara, ou o Shopping Oiapoque, em Belo Horizonte (Vilas Bôas, 2009). Não podemos deixar de incluir China Town, em Nova York, e o famoso Mercado da Seda (Xiu Shui), em Pequim. O exemplo de Caruaru é particularmente interessante dada a centralidade que há mais de 150 anos a feira da cidade possui internamente a um sistema regional que alcança muitas cidades de todo o nordeste brasileiro. Além disso, mostra como a existência prévia de um sistema migratório popular, de pernambucanos para São Paulo, provê uma estrutura útil para as dinâmicas da globalização popular (Lyra, 2005). Mercadorias trazidas de Ciudad del Este ou da Rua 25 de Março alimentam a Feira do Paraguai, o setor de gadgets globais da Feira de Caruaru, que, por sua vez, alimenta uma grande quantidade de outras feiras menores e pequenos comerciantes nordeste afora. A Feira do Paraguai, setor da Feira de Caruaru, permite visualizar bem como a capilaridade do sistema mundial não hegemônico estende-se, por meio da globalização popular, chegando a lugares distantes e inusitados.

$\mathrm{Na}$ verdade, estes nós do sistema mundial não hegemônico são mercados de maior ou menor envergadura. Os mercados podem fazer o papel de elos entre diferentes fluxos mediante a articulação de redes com objetivos semelhantes e em comum. Assim, várias redes pequenas em extensão acabam gerando um efeito de longo alcance. Os mercados podem tanto ser pontos de articulação dessas redes como o lócus de articulação entre as atividades da economia ilegal global e as da economia (i)lícita global. Ciudad del Este, dada a sua magnitude, é um exemplo claro disso, com a sua associação a enormes e poderosos esquemas de lavagens de dinheiro e a presença de milhares de "sacoleiros". A Rua 25 de Março em São Paulo, também, dada a sua dimensão (ainda que menor que Ciudad del Este) é um ótimo exemplo de um mercado, um nó do sistema mundial não hegemônico, que mostra a presença de grandes atravessadores e miríades de redes de "sacoleiros". Cabe reforçar que há uma diferenciação interna neste universo, apresentando-se sob a forma de uma estrutura piramidal estabelecida internamente às redes de transações entre grandes e pequenos fornecedores, por exemplo. Internamente a tal estrutura pode haver agentes $\mathrm{e}$ redes sociais envolvidos em diferentes momentos e aspectos de atividades econômicas lícitas, (i)lícitas e ilegais. Nada impede que se passe do sistema não hegemônico para o hegemônico e vice-versa. O sistema mundial não hegemônico pode servir como uma maneira de realizar acumulação primitiva de capital. Como tal, pode ser útil para um capitalista individual como uma forma de acumular, em um determinado momento de sua trajetória econômica, ou pode ser permanentemente utilizado para tal fim. Entretanto, é preciso notar com Chang que

[...] a proliferação de produtos contra-feitos adota quase as mesmas rotas do capitalismo global com táticas "glocais" de manobras até mais flexíveis e ágeis para escapar das batidas nacionais. [...] Logo(marcas) falsas estão se espalhando ubiquamente em todo o mundo e estão constituindo, com sucesso, um mercado global que simultaneamente duplica a criação de redes do capitalismo e o desestabiliza como uma sub-versão contra-feita (2004, p. 223).

A globalização popular está formada por nós, os mercados populares, e fluxos, as viagens. Assim como há nós maiores, há fluxos maiores ou menores que cobrem grandes ou pequenas dis- 
tâncias. Assim, as redes sociais transnacionais que animam os fluxos internos ao sistema mundial não hegemônico são compostas por migrantes de vários tipos (ver Telles, 2009, pp. 159-160). Muitos são verdadeiros comerciantes nômades globais contemporâneos. A diáspora chinesa, a maior do mundo contemporâneo, tem um papel fundamental na globalização popular que nela em grande medida se apoia. Não por acaso encontram-se cada vez mais migrantes chineses, em geral cantoneses, associados ao comércio do sistema mundial não-hegemônico (no caso de Lisboa, ver Mapril, 2002). A Galeria Pagé, por exemplo, o edifício mais globalizado da Rua 25 de Março, em São Paulo, está dominada pela presença chinesa, fato que reflete a crescente influência desses migrantes neste importante nó da globalização popular. A história da Rua 25 de Março (Nascimento, 2006) é ilustrativa de certas dinâmicas centrais do sistema como um todo. Aquela regiāo paulistana foi, desde o final do século XIX, caracterizada pela presença sírio-libanesa que, a partir dos últimos anos do século XX, passou a ser deslocada pela presença asiática, coreana e, sobretudo, chinesa. A diáspora sírio-libanesa conforma a segunda mais importante rede de agentes sociais para o sistema mundial não hegemônico. Costurada ao longo de muito tempo e baseada em redes de parentesco e amizade, afinidade religiosa e política, a diáspora síriolibanesa foi relevante para a internacionalização

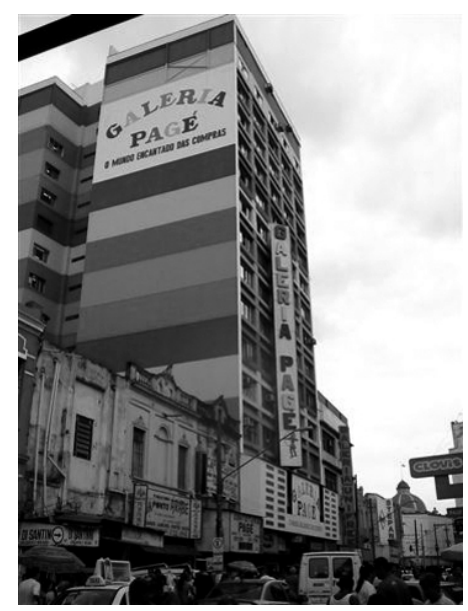

Galeria Pagé: o edifício globalizado da Rua 25 de Março (São Paulo). Foto: Gustavo Lins Ribeiro

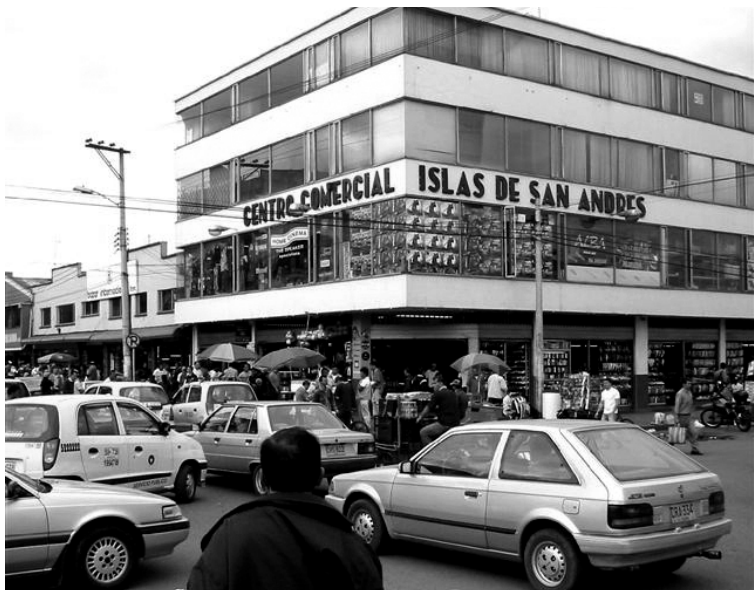

San Andrecito da Rua 38 em Bogotá.

Foto: Gustavo Lins Ribeiro

da região da Rua 25 de Março e para o estabelecimento de vínculos e práticas comerciais internacionais, com a resultante transformação daquela área em espaço urbano etnicamente diferenciado. Desde finais da década de 1950, milhares de descendentes de árabes também tornaram-se centrais para o comércio da transfronteira Ciudad del Este/Foz do Iguaçu (Arruda, 2007). A migração libanesa foi igualmente crucial no estabelecimento de uma rede de San Andresitos, na Colômbia. Em algumas situações, como na Rua 25 de Março, em Ciudad del Este/Foz do Iguaçu e na região do Saara, no Rio de Janeiro, a migração chinesa vem deslocando a libanesa, gerando novas segmentaçôes étnicas e, potencialmente, novos conflitos interétnicos (Cunha, 2005). Em outras situações, como nas Feiras do Paraguai em Brasília (Rocha, 2007) e Caruaru, ou em Tepito (Alarcón, 2008), na Cidade do México, também se nota uma crescente presença chinesa. De fato, a globalização popular pode ter se transformado no maior propulsor do crescimento da migração chinesa no Brasil e em outros países, como Argentina e México. Diásporas da envergadura da chinesa e da libanesa proveem uma base altamente orgânica para o desenvolvimento de atividades transnacionais, já que redes migratórias podem propiciar confiança e previsibilidade, como está implícito na noção chinesa de guanxi, em um universo onde é baixa a capacidade de implementação da lei (ver Machado, 2009; Silva, 2008, 2009). 
Algumas consideraçôes sobre a esfera da produção

Os trabalhos sobre aspectos específicos do sistema mundial não hegemônico concentram-se fortemente na circulação de pessoas e mercadorias (ver, por exemplo, Machado, 2005, 2009; Nascimento, 2006; Konstantinov, 1996; MacGaffey e Bazenguissa-Ganga, 2000). O fato de, internamente a este universo, os mercados se destacarem explica-se por suas características de espaços públicos; neles é possível fazer pesquisa de campo. Falar desse sistema considerando também as unidades produtivas que o compõem implica uma tarefa etnográfica muito mais árdua. As fábricas não são exatamente espaços públicos. Ao contrário, como já indicava Marx (1977), os capitalistas fazem questão de deixar fora do alcance dos olhos as transformaçóes que lá ocorrem. Isso é mais intenso quando se trata das unidades de produção vinculadas à economia (i)lícita global.

Se fôssemos começar por onde as mercadorias são produzidas, centros fundamentais do sistema encontram-se na Ásia, em lugares como Taiwan, Coréia do Sul, Singapura, Malásia e, em especial, China. O fato de diferentes áreas da Ásia terem se tornado o centro da produção das mercadorias do sistema mundial não hegemônico relaciona-se, em grande medida, com o poder da economia do Japão, um dos maiores mercados de artigos de luxo. Taiwan, Coréia do Sul e Hong Kong, por exemplo, foram grandes centros produtores de mercadorias falsas para o Japão. Entretanto, a China logo se tornou a principal fornecedora de produtos falsos para todo o mundo: "hoje, mesmo em Taiwan produtos Louis Vuitton falsificados são 'importados' principalmente da China" (Chang, 2004, p. 230). Assim, este país não é apenas a menina dos olhos da globalização hegemônica (ver, por exemplo, Guthrie, 2006), é também o centro da globalização não-hegemônica, da globalização popular. De fato, qualquer pesquisa sobre a produção de bugigangas globais e de produtos "piratas" certamente teria que privilegiar a província de Guangdong, no sul da China, onde o boom econômico das últimas décadas tem se expressado também em uma enorme produção de produtos para os mercados da globalização popular. ${ }^{4}$ As cidades de Dongguan, Shen- zhen, Hong Kong e Guangzhou (Cantão) conformam, provavelmente, a maior zona de produção de mercadorias do sistema mundial não hegemônico, o começo de uma cadeia de mercadorias na qual os lucros se acumulam fantasticamente.

Guangdong tem sido historicamente uma grande porta para o comércio com o mundo e para a emigração formadora da diáspora chinesa. A importância de Guangdong e de sua capital, Cantão, como meio de contato com o Ocidente, levou os portugueses a colonizarem Macau de 1557 a 1999. Em 1841, também na foz do rio das Pérolas, os ingleses fundariam Hong Kong, um entreposto do império britânico. A soberania chinesa sobre Hong Kong seria devolvida em 1997. Hoje, Macau e Hong Kong são Regiōes Administrativas Especiais da República Popular da China, de acordo com o modelo "um país, dois sistemas". Mais importante ainda para a compreensão desta área como centro do sistema mundial não-hegemônico foi o fabuloso desenvolvimento, na China Continental, de Shenzhen que, em 1980, se tornou a primeira Zona Econômica Especial. Localizada há poucos quilômetros de Hong Kong, na região econômica mais dinâmica da China, o delta do Rio das Pérolas, Shenzhen é o coração do sistema produtivo das mercadorias da globalização popular.

Hong Kong e Shenzhen desenvolvem diferentes relaçōes complementares. A ex-colônia britânica é uma grande porta de entrada para os "sacoleiros" de todo o mundo que, cada vez mais, adentram o território da China continental e vão a Shenzhen portando vistos de um dia, adquiridos em Hong Kong, para fazer suas compras em shopping centers como o de Luohu. Muitos destes "turistas-compradores", uma designação simplificada dos praticantes do comércio de longa distância típico da globalização popular, podem fazer suas compras no que talvez seja o edifício mais globalizado do sistema mundial não hegemônico, Chungking Mansions, em Hong Kong (Mathews, 2008). Construído na década de 1960, são cinco blocos de 17 andares. Seus dois primeiros andares são formados por lojinhas para compradores de mais de cem nacionalidades, o restante do edifício são restaurantes e pensões que abrigam "sacoleiros" provenientes especialmente da Ásia, do Oriente Médio e da África. 


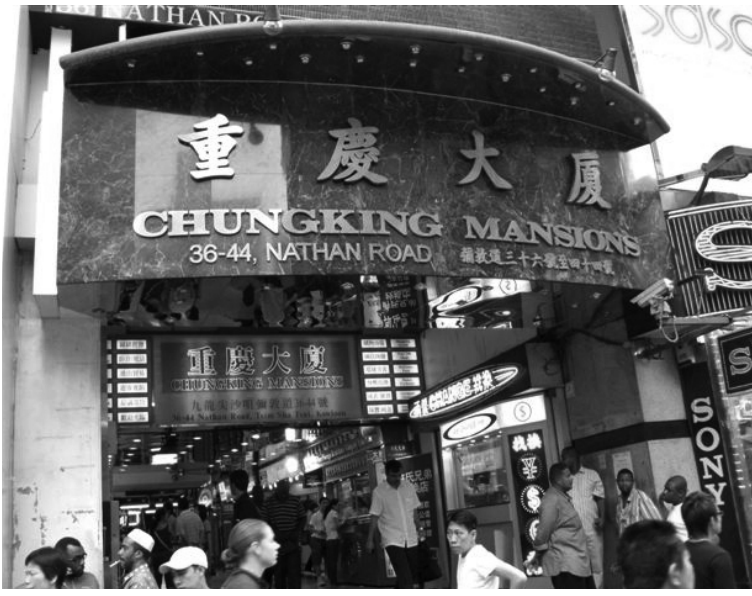

Chungking Mansions - o edifício mais globalizado do sistema mundial não hegemônico (Hong Kong). Foto: Gustavo Lins Ribeiro

Estas áreas da China têm uma história de produção de cópias que começa ao menos no século XIX (Machado, 2009). Copiavam-se bens ocidentais para venda interna na China e, inversamente, bens chineses para venda no Ocidente. No que diz respeito à produção de mercadorias para o sistema mundial não-hegemônico, Chang chega a falar de "indústria global de contrafaçōes" (2004, p. 224). A (re)produção de cópias de superlogomarcas "ainda segue o modo tradicional de produção de mercadorias, baseado na divisão e na exploração globais do trabalho, no sistema de produção de fábrica e, mais especificamente, no agora mais do que conhecido sistema de terceirização pelo mundo afora" (Idem, p. 204). Na América do Sul, o Paraguai é um centro produtor conhecido. No Brasil, há fabriquetas de cópias de marcas famosas de tênis em Minas Gerais, por exemplo (Santos, 2008).

\section{Por que existe a globalização popular? Originais e cópias}

Mais além dos elementos já amplamente discutidos na literatura sobre economia informal como o não-pagamento de impostos, a ausência de mecanismos de responsabilização nas transações comerciais e de prestações de serviços, a vulnerabilidade dos trabalhadores envolvidos - a globalização popular se apoia fortemente na existência de superlogomarcas e na presente capacidade de realizar cópias tão perfeitas que se torna cada vez mais difícil ou irrelevante identificar as diferenças entre produtos falsificados e seus originais.

Em grande medida, os produtos "piratas" baseiam sua enorme rentabilidade na produção de cópias do que Hsiao-hung Chang (2004) chamou de superlogomarcas para designar o conjunto de marcas celebradas internacionalmente e que se tornaram símbolos globais de status privilegiado (Louis Vuitton, Fendi, Victor Hugo, Armani, Dior, Gucci, Nike, Adidas, Rolex, Ray-Ban, Sony e muitas outras). A superlogomarca está ancorada em um excedente de valor excepcional, amplamente baseado em seu valor simbólico, naquilo que representa como símbolo de status para os consumidores. Este delta é acrescentado a uma mercadoria pela manutenção do monopólio encarnado na propriedade da superlogomarca. Manter, manipular e administrar superlogomarcas é um modo, praticado por grandes corporaçôes, de possuir nichos exclusivos no mercado de símbolos globais de status e, em última instância, de incrementar enormemente seus rendimentos. Esses nichos são estratégicos para a acumulação das firmas capitalistas. Assim, a pirataria significa uma ameaça a um dos núcleos duros da reprodução do capitalismo, qual seja, a detenção de direitos de propriedade sobre determinadas mercadorias, uma vez que tais direitos permitem, justamente, a manutenção dos nichos.

A diferença entre o valor real do objeto específico e seu extraordinário valor simbólico excedente é o que impulsiona o mercado de cópias de superlogomarcas, sempre vendidas, claro, a preços muito menores do que os "originais". Além do não pagamento de impostos, típico das economias informais, o preço baixo das cópias vem de uma combinação de fatores, entre os quais destaco a superexploração de uma força de trabalho precarizada (em Shenzhen, por exemplo, são migrantes, em geral, recentemente proletarizados, ver Machado, 2009); a não remuneração de uma série de fatores que entram na composição do preço do bem de luxo, como, por exemplo, na indústria da alta moda, desfiles, revistas, publicidade e lojas sofisticadas; o uso do mercado formal como campo de provas, isto é, fazer cópias apenas dos modelos de uma superlogomarca de maior sucesso de vendas. 
As superlogomarcas, originais ou cópias, desempenham papel central na economia simbólica do luxo, numa época em que a distinção de status se confunde com a capacidade de possuir determinados objetos e manipular imagens que conferem aos consumidores identidades sociais diferenciadas (Lima, 2008; Santos, 2008). As cópias permitem manipulação consciente, por parte dos consumidores, dos jogos sociais baseados na distinção, que são formas de criar, manter e reproduzir status. Em última instância, isso significa formas de manipular impressôes nas interaçôes sociais com fins muito diversos, mas que acabam redundando em busca de poder pessoal em uma sociedade individualista e consumista.

A indústria de cópias engatilha uma disputa pelo controle do extraordinário valor agregado pela superlogomarca às mercadorias. Entretanto, o impacto da cópia sobre a indústria de bens autênticos não é necessariamente negativo. Mario de Andrade já dizia que a cópia valoriza o original. De fato, quanto maior o número de cópias, mais valorizado será o original, em especial, para um segmento cada vez mais restrito de connaisseurs, capazes de aferir autenticidade a objetos/símbolos verdadeiramente originais e, assim, portadores dos significados de distinção social mais desejados. $\mathrm{Na}$ realidade, as cópias subdividem-se em diferentes categorias. As de terceira linha são imitações burdas, com erros grosseiros como a grafia errada da superlogomarca. As de segunda linha já são réplicas bastante razoáveis, enquanto as de primeira linha podem ser verdadeiros simulacros, cuja falsidade às vezes só é detectada por especialistas. $\mathrm{O}$ preço dos produtos vária de acordo com a qualidade da cópia. Corre a lenda que, em Shenzhen, existem fábricas que produzem bens originais durante o dia e falsificados durante a noite. Neste caso, não haveria diferença entre o original e a cópia a não ser a superlogomarca aderida ao primeiro. A crescente qualidade das cópias bem pode ser o que atraiu consumidores de classe média e classe média alta a fazer compras em nós do sistema mundial não hegemônico como o Shopping Oiapoque, em Belo Horizonte, e a Feira do Paraguai, em Brasília. De qualquer modo, este é um mercado atravessado pela dinâmica da moda, o que o torna certamente mais volátil e caprichoso.
As cópias de superlogomarcas de roupas, sapatos e acessórios estão perdendo o seu lugar de principal fonte de lucros da indústria de produtos falsos para DVDs e programas pirateados. Isto é coerente com a hegemonia do capitalismo eletrônico-informático e com sua flexibilidade interna, em especial com sua capacidade de reprodução de cópias perfeitas, de simulacros. É cada vez mais simples copiar músicas, filmes, imagens, textos e outros materiais protegidos por copyright, da internet ou de outras fontes de tecnologia digital. As modificaçōes introduzidas por novas tecnologias de reprodução nos últimos anos são rapidamente apropriadas, não apenas por adolescentes no recesso de suas casas, mas por pessoas interessadas em fazer dinheiro em ruas e mercados do sistema mundial não hegemônico. O sistema normativo que procura regular a propriedade intelectual das superlogomarcas globais e, em especial, de bens culturais capazes de ser reproduzidos eletronicamente, vai na contramão da inovação tecnológica contemporânea que permite uma grande potencialização de indivíduos, redes, e de sua capacidade de fazer cópias. Ao não dar conta das novas dinâmicas e das múltiplas e inventivas apropriações que constantemente são realizadas por milhôes de pessoas em todo o mundo, o sistema normativo atual prefere criminalizar e estigmatizar tal universo. Assim, transformou-se em um empecilho para a liberação de uma gigantesca energia empreendedora e criativa localizada em diferentes partes do globo e que termina por se realizar nas operaçôes que, com frequência, ocorrem sob o guarda-chuva do sistema mundial não hegemônico. Na prática, a "pirataria” revela o valor excedente absurdo que é agregado à mercadoria pela propriedade da superlogomarca. Como o capitalismo é baseado na apropriação socialmente sancionada de excedentes, ao denunciar este excedente extraordinário, a "pirataria" tem um potencial subversivo que, como vimos, atinge um dos núcleos duros do capitalismo, ao mesmo tempo em que se imbrica contraditoriamente com ele, uma vez que se casa com as próprias necessidades de consumo, de (re) produção de identidades sociais e da distinção sob a égide do capitalismo eletrônico-informático.

$\mathrm{O}$ impulso estrutural dado pelas tecnologias contemporâneas de reprodução e pelo aumento da 
capacidade de se comunicar e viajar para distintos lugares leva a crer que a globalização popular prosseguirá consolidando-se e estreitando, heterodoxamente, os elos entre os diversos nós do sistema mundial não hegemônico.

\section{Notas}

1 Há anos, com estudantes da Universidade de Brasília, pesquisamos o que chamo de "outras globalizações políticas e econômicas”, formas de globalização de baixo para cima (Ribeiro, 2006, 2006a, 2007, 2009, 2009a, 2009b). Neste artigo, interessam-me apenas as "outras globalizações econômicas". Muitas das informações aqui presentes relacionam-se com os trabalhos de A. G. Souza (2000); Figueiredo (2001); Nascimento (2006); Rocha (2007); Santos (2008); Lima (2008).

2 Esta definição funde dois conceitos de economia política marxista. O primeiro, sistema mundial, ao qual já me referi, e o segundo, de hegemonia, de inspiração gramsciana. Por hegemonia, entendo o exercício naturalizado e silencioso do poder, a naturalização, pelos diferentes grupos e classes sociais que formam uma sociedade, das formas socialmente apropriadas de reprodução da vida social.

3 A noção de espaço social transfronteiriço (Jimenez Marcano, 1996) permite entender as relações sociais, culturais, políticas e de parentesco que os agentes sociais desenvolvem em áreas fronteiriças, onde a fronteira opera como um aparato taxonômico complexo e bastante flexível. Muita da flexibilidade que os agentes sociais experimentam em zonas fronteiriças se deve à ineficiência dos agentes do Estado ou à sua conivência com outros agentes sociais que operam internamente ao espaço transfronteiriço. Uma vez que os espaços sociais transfronteiriços colocam em xeque a lógica classificatória do Estado-nação, os maiores dentre eles são, em geral, universos transnacionais propensos a ser territórios globais fragmentados, conectados aos circuitos globais de pessoas, bens e informação. As fronteiras são frequentemente reconhecidas como lugares onde os limites do poder do Estado são postos em xeque por agentes da globalização popular (Abraham e Van Schendel, 2005, p. 14; ver também Naím, 2005). Abraham e Van Schendel (2005, p. 22ss) consideram as fronteiras um espaço típico para o desenvolvimento do (i)lícito, fato favorecido pela "interseção de múltiplas autoridades" competindo entre si, já que "Estados vizinhos frequentemente têm pontos de vista diferentes sobre a lei e a licitude". Eles exemplificam com as fronteiras entre Índia, Bangladesh, China e Miamar e mencionam os cassinos e as compras através de fronteiras como ocorrências comuns.

4 Boa parte do que segue baseia-se em Machado (2009).

\section{BIBLIOGRAFIA}

ABRAHAM, Itty \& SCHENDEL, Willem Van (2005), "Introduction: the making of illicitness", in Schendel e Abraham (orgs.), Illicit flows and criminal things, Bloomington, Indiana University Press, pp. 1-37.

ALARCÓN, Sandra. (2008), El tianguis global. Cidade do México, Universidad Iberoamericana.

ARRUDA, Aline Maria Thomé. (2007), A presença libanesa em Foz do Iguaçu (Brasil) e Ciudad del Este (Paraguai). Dissertação de mestrado, Centro de Pesquisas e Pós-Graduação sobre as Américas, Universidade de Brasília.

CHANG, Hsiao-hung. (2004), "Fake logos, fake theory, fake globalization". Inter-Asia Cultural Studies, 5 (2): 222-236.

CUNHA, Neiva Vieira da. (2005), "Libaneses \& chineses: sucessão, conflito e disputa numa rua de comércio do Rio de Janeiro". Trabalho apresentado na VI Reunião de Antropologia do Mercosul, Montevidéu, 16 a 18 de novembro de 2005.

FIGUEIREDO, Breno Einstein. (2001), "De feirantes da feira do Paraguai a micro-empresários". Trabalho de conclusão de curso de graduação. Departamento de Antropologia, Universidade de Brasília.

GALLANT, Thomas W. (1999), "Brigandage, piracy, capitalism, and state-formation: transnational crime from a historical world-system perspective”. In: Josiah McC. Heyman (org.), States and illegal practices. Oxford/Nova York, Berg, pp. 25-61.

GARCÍA CANCLINI, Néstor. (1982), Las culturas populares en el capitalismo. México, Nueva Imagen. 
GUTHRIE, Doug. (2006), China and globalization: the social, economic and political transformation of Chinese society. Nova York, Routledge.

HEYMAN, Josiah McC. \& SMART, Alan. (1999), "States and illegal practices: an overview”, in Josiah McC. Heyman (org.), States and illegal practices, Oxford/Nova York, Berg, pp. 1-24.

JIMENEZ MARCANO, Elvia. (1996), La construcción de espacios sociales transfronterizos entre Santa Elena de Uairen (Venezuela) y Villa Pacaraima (Brasil). Tese de doutorado, Programa Conjunto de Doutorado em Estudos Comparados de América Latina e Caribe, FLACSO/ Universidade de Brasília.

KONSTAM, Angus. (2002), The history of pirates. Guilford, Connecticut, The Globe Pequot Press.

KONSTANTINOV, Yulian. (1996), "Patterns of reinterpretation: trader tourism in the Balkans (Bulgaria) as a picaresque metaphorical enactment of post-totalitarianism." American Ethnologist, 23 (4): 762-782.

LIMA, Carolina Vicente Ferreira. (2008), "Consumo feminino de produtos de superlogomarcas e produtos piratas de superlogomarcas". Trabalho de conclusão de curso. Departamento de Antropologia, Universidade de Brasília.

LINEBAUGH, Peter \& REDIKER, Marcus. (2000), The many-headed hydra: sailors, slaves, commoners, and the hidden history of the Revolutionary Atlantic. Boston, Beacon Press.

LOMNITZ ADLER, Larissa. (1988), "Informal exchange networks in formal systems: a theoretical model". American Anthropologist, 90 (1): 42-55.

(1994), "Redes informales de intercambio en sistemas formales", in Redes sociales, cultura y poder: ensayos de antropología latinoamericana, México, Miguel Ángel Porrúa, pp. 152-166.

LYRA, Maria Rejane Souza de Britto. (2005), "Sulanca $\mathrm{x}$ muamba: rede social que alimenta a migração de retorno". São Paulo em Perspectiva, 19 (4): 144-154.

MacGAFFEY, Janet \& BAZENGUISSA-GANGA, Rémy. (2000), Congo-Paris: transnational tra- ders on the margins of the law. Oxford/Bloomington, The International African Institute/ James Currey/Indiana University Press.

MACHADO, Rosana Pinheiro. (2005), "A Garantia soy yo": etnografia das práticas comerciais entre camelôs e sacoleiros na cidade de Porto Alegre e na fronteira Brasil/Paraguai. Dissertação de Mestrado, Programa de Pós-Graduação em Antropologia Social, Universidade Federal do Rio Grande do Sul. . (2009), Made in China: produção e circulação de mercadorias no circuito China-Paraguai-Brasil. Tese de doutorado, Programa de Pós-Graduação em Antropologia Social, Universidade Federal do Rio Grande do Sul.

MATHEWS, Gordon. (2008), "Chungking mansions: a center of 'low-end globalization". Ethnology, XLVI (2): 169-183.

MAPRIL, José. (2002), "De Wenzhou ao Martim Moniz: práticas diaspóricas e a (re)negociação identitária do local”. Ethnologia, 12-14: 253294.

MARX, Karl. (1977), Capital: a critique of political economy. Nova York, Random Press.

NAÍM, Moisés. (2005), Illicit: how smugglers, traffickers, and copycats are hijacking the global economy. Nova York, Doubleday.

NASCIMENTO, Munich. (2006), "A Rua 25 de Março e a imigração sírio-libanesa para São Paulo". Trabalho de conclusão de curso. Departamento de Antropologia, Universidade de Brasília.

NORDSTROM, Carolyn. (2007), Global outlaws: crime, money, and power in the contemporary world. Berkeley, University of California Press.

RABOSSI, Fernando. (2004), Nas ruas de Ciudad del Este: vidas e vendas num mercado de fronteira. Tese de doutorado em Antropologia, Museu Nacional, Universidade Federal do Rio de Janeiro.

RIBEIRO, Gustavo Lins. (1991), Empresas transnacionais: um grande projeto por dentro. São Paulo, Marco Zero.

. (2006), "Other globalizations: alternative transnational processes and agents". Série Antropologia, 389, Universidade de Brasília.

. (2006a), "Economic globalization from Below”. Etnográfica, X (2): 233-249. 
(2007), "El sistema mundial no hegemónico y la globalización popular". Anuario de Estudios en Antropología Social 2006, 7-19, Buenos Aires.

(2008), "Poder, redes e ideologia no campo do desenvolvimento". Novos Estudos Cebrap, 80: 109-125.

. (2009), "De Guangdong a Caruaru". Le Monde Diplomatique - Brasil, 2 (20): 8-9, mar.

. (2009a), "Non-hegemonic globalizations: alternative transnational processes and agents". Anthropological Theory, 9 (3): 1-33. . (2009b), "De Guangdong a Caruaru". Revista Brasileira de Sociologia da Emoção 8 (24): 510-522.

ROCHA, Rachel Dubard de Moura. (2007), "Nem daqui, nem da China. Um estudo antropológico sobre identidades multifacetadas dos migrantes chineses na Feira dos Importados, Brasília, D.F.”. Trabalho de conclusão de curso. Departamento de Antropologia, Universidade de Brasília.

SANTOS, Gustavo Paulo. (2008), "Consumo de metáforas: conotaçôes e usos sociais de logomarcas em estudos comparados". Trabalho de conclusão de curso, Departamento de Antropologia, Universidade de Brasília.

SCHADEN, Erica Mancuso. (2005), "Imigração árabe: um olhar sobre a rua 25 de Março". Relatório parcial de pesquisa, Universidade Estadual de Campinas (mimeo.).

SCHIAVONI, Lídia. (1993), Frágiles pasos, pesadas cargas: las comerciantes fronterizas de PosadasEncarnación. Assunção/Posadas, Centro Paraguayo de Estudios Sociológicos/Editorial Universitária Universidad Nacional de Misiones.

SILVA, Marcos de Araújo Silva. (2008), Guanxi nos trópicos: um estudo sobre a diáspora chinesa em Pernambuco. Dissertação de mestrado, Programa de Pós-Graduação em Antropologia, Universidade Federal de Pernambuco.

. (2009), "This isn't contraband, I'm clean": a study of borders of incorporation and exclusion among Chinese immigrants in Pernambuco. Vibrant, 6: 152-169.

SOUSA, Rosinaldo Silva de. (2004), "Narcotráfico y economía ilícita: las redes del crimen organi- zado en Río de Janeiro". Revista Mexicana de Sociologia, 66 (1): 141-192.

. (2006), Os cocaleros do Chapare: coca, cocaina e politicas internacionais antidrogas na Bolivia. Tese de doutorado, Programa de PósGraduação em Antropologia Social, Universidade de Brasília.

SOUZA, Angelo José Sátyro de. (2000), "Feira do Paraguai: território e poder - história e memória”. Trabalho de conclusão de curso, Departamento de Antropologia, Universidade de Brasília.

TARRIUS, Alain. (2007), La remontée des Suds: afghans et marocains en Europe Méridionale. Paris, L'Aube.

TELLES, Vera da Silva. (2009), "Ilegalismos urbanos e a cidade". Novos Estudos Cebrap, 84: 152-173.

TULLIS, LaMond. (1995), Unintended consequences: illegal drugs and drug policies in nine countries. Boulder, CO, Lynne Reiner.

VILAS BÔAS, Cristina Aparecida. (2009), Ter para ser socialmente: representaçóes e práticas do consumo no shopping Oiapoque, Belo Horizonte. Dissertação de mestrado em Ciências Sociais, Pontifícia Universidade Católica de Minas Gerais.

WALLERSTEIN, Immanuel. (1974), The modern world-system. Vol. 1: Capitalist agriculture and the origins of the European world-economy in the Sixteenth Century. Nova York/Londres, Academic Press. . (2006), World-systems analysis. Durham/ Londres, Duke University Press.

WOLF, Eric. (1982), Europe and the people without history. Berkeley, University of California Press. 


\section{A GLOBALIZAÇÃO POPULAR E O SISTEMA MUNDIAL NÃO HEGEMÔNICO}

\section{Gustavo Lins Ribeiro}

Palavras-chave: Transnacionalismo; Pirataria; Falsificações; Contrabando.

Existe uma globalização econômica nãohegemônica formada por mercados populares e fluxos de comércio animados, em grande medida, por gente do povo e não por representantes das elites. Essas atividades são consideradas ilegais, "contrabando", e as mercadorias, produtos piratas. Tais redes comerciais são ilegítimas do ponto de vista dos poderosos, que as combatem em nome da legalidade. Este artigo discute o que é legal/ilegal, lícito/ ilícito, lançando mão da noção de (i)lícito para dar conta das ambivalências e das contradições neste domínio. Cunho a noção de sistema mundial não-hegemônico, analiticamente dividido em duas esferas interconectadas: o "crime organizado global" e a "globalização popular". Por fim, faço considerações sobre as razóes da existência da globalização popular e a formação do preço de suas mercadorias.

\section{ECONOMIC GLOBALIZATION FROM BELOW THE NON- HEGEMONIC WORLD SYSTEM}

\section{Gustavo Lins Ribeiro}

Keywords: Transnationalism; Piracy; Counterfeits; Smuggling.

There is an economic non-hegemonic globalization made up of street markets and trading flows that are animated by actors of the lower classes and not by the elites. These activities are considered as illegal, as "smuggling." The commodities traded are often classified as piracy. In consequence, the trading networks are seen by the powerful as illegitimate and are confronted with repression in the name of legality. I thus debate what is legal/illegal, licit/illicit and make use of the notion of the (il)licit to tackle with the ambivalences and contradictions of this domain. I offer the notion of some non-hegemonic world system, analytically divided into two interconnected spheres: the "global organized crime" and the economic globalization from below. Lastly, I make some considerations on why economic globalization from below exists and how the price of its commodities is made up.

\section{LA MONDIALISATION POPULAIRE ET LE SYSTÈME MONDIAL NON HÉGÉMONIQUE}

\author{
Gustavo Lins Ribeiro
}

Mots-clés: Transnationalisme; Piratage, Falsifications; Contrebande.

Il existe une mondialisation économique non hégémonique formée par les marchés populaires et les échanges commerciaux animés, en grande partie, par des personnes ordinaires et non par des représentants des élites. Ces activités sont considérées illégales, de la "contrebande», et les marchandises, des contrefaçons. De tels réseaux commerciaux sont illégitimes du point de vue des de ceux qui détiennent le pouvoir, qui les combatent au nom de la légalité. Cet article aborde la question de ce qui est légal/illégal, licite/ illicite, sans considérer la notion de (il) licite pour comprendre les ambivalences et les contradictions dans ce domaine. Je propose la notion de système mondial non hégémonique, analytiquement divisé en deux sphères interconnectés: le "crime mondial organisé" et la "mondialisation populaire”. En conclusion, je présente mes considérations sur les raisons de l'existence de la mondialisation populaire et le prix de ses marchandises. 